\title{
Antioxidant effect of mango seed extract and butylated hydroxytoluene in bologna-type mortadella during storage
}

\author{
Efeito antioxidante do extrato da semente da manga e do butilato de \\ hidroxitolueno em mortadela tipo bologna durante a estocagem
}

Ana Lúcia Fernandes PEREIRA ${ }^{1 *}$, Tatiana Fontoura VIDAL ${ }^{1}$, Marcílio Costa TEIXEIRA ${ }^{1}$, Patrícia Freitas de OLIVEIRA ${ }^{1}$, Roberto Cláudio Fernandes Franco POMPEU ${ }^{1}$, Marieta Maria Martins VIEIRA ${ }^{1}$, Jorge Fernando Fuentes ZAPATA ${ }^{1}$

\begin{abstract}
The effects of mango seed extract (MSE) and butylated hydroxytoluene (BHT) on pH, lipid oxidation, and color of Bologna-type mortadella during refrigerated storage for 21 days were studied. Bologna-type mortadella samples were formulated to contain $0.1 \%$ MSE, $0.2 \%$ MSE, or $0.01 \%$ BHT. After 14 days of storage, the products containing MSE 0.1 or $0.2 \%$ had higher pH values than those containing BHT $0.01 \%$. Lipid oxidation values increased with storage time but were not affected by the type of antioxidant. The highest values for color parameter $\mathrm{L}^{*}$ were observed for mortadella containing BHT $0.01 \%$ after 7,14 , and 21 days of storage. Values for the color parameters $\mathrm{a}^{\star}$ and $\mathrm{b}^{\star}$ tended to decrease during mortadella storage. Products containing 0.1 or $0.2 \%$ MSE showed higher values for color parameter $\mathrm{a}^{\star}$ and lower values for color parameter $b^{*}$ compared to those containing $0.01 \%$ BHT. It can be concluded that MSE can be used in 0.1 or $0.2 \%$ levels in Bologna-type mortadella with similar or better antioxidant effects than those of BHT $0.01 \%$.
\end{abstract}

Keywords: natural antioxidant; mango seed; lipid oxidation; color.

\section{Resumo}

Foram estudados os efeitos do extrato da semente da manga (ESM) e do butilato de hidroxitolueno (BHT) sobre o pH, a estabilidade dos lipídios e a cor de mortadelas tipo Bologna durante a estocagem sob refrigeração por 21 dias. As mortadelas foram formuladas para conter 0,1\% de ESM, 0,2\% de ESM ou 0,01\% de BHT. Após 14 dias de estocagem, os produtos contendo ESM 0,1\% ou 0,2\% tiveram maiores valores de $\mathrm{pH}$ que aqueles contendo BHT $0,01 \%$. Os valores de oxidação lipídica aumentaram com o tempo de estocagem, não sendo afetada pelo tipo de antioxidante. Os maiores valores do parâmetro de cor L* foram observados para as mortadelas contendo BHT 0,01\% após 7, 14 e 21 dias de estocagem. Os valores para os componentes de cor $\mathrm{a}^{*} \mathrm{e} \mathrm{b}^{*}$ tenderam a reduzir com a estocagem. Os produtos contendo 0,1 ou $0,2 \%$ de ESM mostraram maiores valores para o componente de cor $\mathrm{a}^{\star}$ e menores valores para o componente de cor $\mathrm{b}^{\star}$ quando comparados com aqueles contendo 0,01\% BHT. Desta forma, conclui-se que o ESM pode ser usado nos níveis de 0,1 ou 0,2\% em mortadelas tipo Bologna, apresentando efeito antioxidante similar ou melhor que o BHT 0,01\%.

Palavras-chave: antioxidante natural; semente da manga; oxidação lipídica; cor.

\section{Introduction}

Bologna-type mortadella is a cooked meat product processed as a meat emulsion, which may contain distributed pork fat stripes or cubes, added to with ingredients, and filled into natural or synthetic casings (BRASIL, 2000).

Many factors influence the quality and shelf life of meat products such as Bologna-type mortadella. Studies have shown that lipid oxidation is one of the primary causes of quality loss. Lipid oxidation can induce changes in sensorial quality, nutritive value, and product functionality. These changes are perceived as negative by consumers (SILVA et al., 2003).

Food antioxidants are compounds or substances that are present naturally in some ingredients or are intentionally added as food additive with the aim of inhibiting product oxidation (HALLIWELL, 1996). Thus, their use in the food industry is important to maintain quality, mainly in foods that contain high levels of lipids, such as meat products.

In industrial meat processing, synthetic antioxidants, such as butylated hydroxytoluene (BHT) and butylated hydroxyanisole (BHA), are frequently used in order to inhibit the formation of free radicals and to prevent lipid auto oxidation and food spoilage. Synthetic antioxidants show good stability during processing and storage of high lipid foods. In recent years, however, many countries (Japan and some European countries) have suppressed the use of synthetic antioxidants because of their potential toxicity and carcinogenicity (TANG et al., 2001; WANASUNDARA; SHAHIDI, 1998).

Thus, the demand for antioxidant substances naturally found in fruits and vegetables has increased since the use of those substances in meat products has been considered due

Tecnologia de Alimentos, Universidade Federal do Ceará - UFC, Fortaleza - CE, Brasil, E-mail: anafernandesp@yahoo.com.br

${ }^{*}$ A quem a correspondência deve ser enviada 
to healthy benefits to consumers such as the reduction in the incidence of cardiovascular diseases and cancer. Moreover, natural antioxidants can be more effective in retarding food oxidation (ZANDI; GONDON, 1999; KANG; CHERIAN; SIM, 2001; BUB et al., 2003).

Several studies using rosemary and green tea products have shown that natural antioxidants may be more effective than the synthetic ones (TANG et al., 2001; WANASUNDARA; SHAHIDI, 1998; ZANDI; GONDON, 1999).

Mango (Mangifera indica L.) fruit is one of the most important tropical foods containing carotenoids and phenolic antioxidant compounds. During the processing of mango, the seed is one of the main by-products. The seeds are not currently utilized for any commercial purpose and are discarded as a waste becoming a source of pollution. Nevertheless, mango seeds extract could be used as a source of natural antioxidant additive in food processing (RIBEIRO et al., 2007).

Soong and Barlow (2004) reported that mango seed has a strong antioxidant activity due to its high phenolic compounds content. These authors also observed that mango seed is a good source of of phytosterols such as campesterol, $\beta$-sitosterol, stigmasterol, and also tocopherols.

It has also been reported that mango seed kernel is a good source of gallotannins and condensed tannin-related polyphenols (PURAVANKARA; BOGHRA; SHARMA, 2000; SOONG; BARLOW, 2006). Abdalla et al. (2007) observed that compounds contained in this by-product have potential antioxidant and antimicrobial activities.

Therefore, the objective of this work was to evaluate the antioxidant effect of mango seed extract compared to butylated hydroxytoluene in Bologna-type mortadella during storage at $2{ }^{\circ} \mathrm{C}$ for 21 days.

\section{Materials and methods}

\subsection{Experimental design and statistical analysis}

A split-plot design with three plots (mortadella formulations containing $0.01 \%$ BHT, $0.1 \%$ MSE, or $0.2 \%$ MSE) and four subplots (storage time: $0,7,14$, and 21 days) with four replicates per treatment wereused. Samples containing BHT served as the control treatment. Hence, the experiment used a total of 48 Bologna-type mortadellas.

\subsection{Preparation of mango seed extract}

The extract was prepared from mango seeds obtained as a by-product from a local fruit pulp industry. Mango seeds were dried at $55^{\circ} \mathrm{C}$ for 48 hours and ground to a fine homogeneous powder. Three hexane washings were then applied to extract liposoluble compounds.

The material was then filtered and concentrated by rotary evaporation $\left(50^{\circ} \mathrm{C}\right)$ to obtain the ethanolic extract and the recovered substrate, which was reused for extraction two more times. Extracts were pooled and evaporated to reach $30 \%$ of moisture at $50^{\circ} \mathrm{C}$ in a rotator (Tecnal TE 057, Piracicaba, Brazil) under reduced pressure.

\subsection{Preparation of Bologna-type mortadella}

Forty eight Bologna-type mortadella samples weighing $250 \pm 0.01 \mathrm{~g}$ were prepared by mixing the ingredients described in Table 1. Portions of lean beef $(7.50 \mathrm{~kg})$, lean pork $(5.25 \mathrm{~kg})$, and back fat $(2.25 \mathrm{~kg})$ were ground (Vicris 2524, São Paulo, Brazil) through a plate with holes of $0.8 \mathrm{~cm}$ diameter. The ground meat was divided into three equal portions and frozen at $-18^{\circ} \mathrm{C}$ for 24 hours before processing.

For each mortadella batch, ground beef and pork were placed in a cutter (Scharfen D5810 Witten, Germany) and blended with the antioxidants (BHT $0.01 \%$, MSE $0.1 \%$, or MSE $0.2 \%$ ), the curing ingredients, and the back fat. The final meat batter temperature was $8{ }^{\circ} \mathrm{C}$.

Each batch of mixture obtained (mixture of meats and all ingredients) was then filled into $75 \mathrm{~mm}$ synthetic casings and cooked in a water bath (Tecnal TE 057, Piracicaba, Brazil) at $80^{\circ} \mathrm{C}$ to an internal temperature of $78{ }^{\circ} \mathrm{C}$. Bologna-type mortadellas were then chilled in an iced/water bath until an internal temperature of $25{ }^{\circ} \mathrm{C}$. The product temperature was registered throughout the process with an insertion thermometer (Delt DT 700, São Paulo, Brazil).

Bologna-type mortadella samples containing mango seed extract (MSE $0.1 \%$ or MSE $0.2 \%$ ) or butylated hydroxytoluene (BHT $0.01 \%$ ) were then stored at $2{ }^{\circ} \mathrm{C}$ for 21 days.

\subsection{Chemical and physical analysis of Bologna-type mortadellas}

The samples were evaluated for $\mathrm{pH}$ using a digital $\mathrm{pH}$ meter (Digi-Sense ${ }^{\oplus} 5938-10$, Chicago, USA) after homogenizing a $10 \mathrm{~g}$ sample in $10 \mathrm{~mL}$ distilled water (WARRIS, 2003).

Table 1. Composition of Bologna-type mortadella formulated with butylated hydroxytoluene (BHT $0.01 \%$ ) or mango seed extract (MSE $0.1 \%$ or MSE $0.2 \%$ ) as antioxidants.

\begin{tabular}{lc}
\hline \multicolumn{1}{c}{ Meat components } & $\%$ \\
\hline Beef & 50.00 \\
Pork & 35.00 \\
Back fat & 15.00 \\
\hline \multicolumn{1}{c}{ Ingredients and additives } & $\%$ of meat \\
\hline Iced-water & 10.00 \\
Starch & 5.00 \\
Sodium chloride & 1.10 \\
Bologna-type mortadella condiment & 1.00 \\
Cured salt & 0.30 \\
Garlic & 0.30 \\
Antioxidant ${ }^{(1)}$ & BHT 0.01 \\
& MSE 0.10 \\
Sodium tripolyphosphate & MSE 0.20 \\
Spices & 0.25 \\
\hline
\end{tabular}

\footnotetext{
${ }^{(1)}$ One type of antioxidant in each batch.
} 
Lipid oxidation was measured by determining the thiobarbituric acid reactive substances (TBARS) in an acidic extract using the method described by Raharjo, Sofos and Schimidt (1992) and modified by Facco (2002). The rose-pink color produced by the reaction between the malondialdehyde (MDA) and 2-thiobarbituric acid was measured using a spectrophotometer (Ultrospec 2000 Pharmacia/Biotech, Cambridge, England) at $531 \mathrm{~nm}$ wavelength. Lipid oxidation was expressed as TBARS numbers (mg MDA. $\mathrm{kg}^{-1}$ sample).

Color parameters were determined using a Minolta CR300 colorimeter (Tokyo) operating in the CIE system, were $L^{*}$ is lightness, $\mathrm{a}^{*}$ is redness, and $\mathrm{b}^{*}$ is yellowness. The colorimeter was standardized using a white tile (Illuminant D65), and the measurements were made through a $8 \mathrm{~mm}$ port/viewing area (MINOLTA, 1998) on the surface of the product immediately after cutting Bologna-type mortadellas into $1 \mathrm{~cm}$ thick slices.

\subsection{Statistical analysis}

Data were submitted to ANOVA, Tukey test, and regression analysis, in which the interaction among antioxidant treatment and storage time was outspread when it was significant $(\mathrm{p}<0.05)$ (STATISTICAL... 1999). Thus, the applied model was (Equation 1):

$Y i j k=\mu+T i+P(i) j+C K+(T C) i k+\varepsilon i j k$

where Yijk = observation relative to jo Bologna-type mortadella at $\mathrm{k}^{\circ}$ storage time, at $\mathrm{i}^{\mathrm{o}}$ antioxidant treatment; $\mu=$ population average; $\mathrm{Ti}=\mathrm{i}^{\circ}$ antioxidant treatment effect; $\mathrm{i}=0.01 \% \mathrm{BHT}$, $0.1 \%$ MSE and $0.2 \%$ MSE; $P(i) j=$ random effect of $j^{\circ}$ Bolognatype mortadella of $\mathrm{i}^{\circ}$ antioxidant treatment (a type error); $\mathrm{j}=1,2,3$ and 4 replicates; $\mathrm{Ck}=\mathrm{k}^{\mathrm{o}}$ storage time effect; $\mathrm{k}=0$, 7, 14 and 21 days; (TC)ik = interaction among $\mathrm{i}^{\circ}$ antioxidant treatment and $\mathrm{k}^{\circ}$ storage time; $\varepsilon \mathrm{ijk}=$ random effect of $\mathrm{j}^{\circ}$ Bolognatype mortadella, in $\mathrm{k}^{\mathrm{o}}$ storage time, of $\mathrm{i}^{\circ}$ antioxidant treatment (b type error).

\section{Results and discussion}

An interaction $(\mathrm{p}<0.05)$ between the type of antioxidant and the storage time was observed for Bologna-type mortadella $\mathrm{pH}$ values. Data are shown in Table 2.

The type of antioxidant showed significant $(\mathrm{p}<0.05)$ effect on mortadella $\mathrm{pH}$ after 14 days storage time, when those products containing MSE 0.1 or $0.2 \%$ had higher $\mathrm{pH}$ values than those containing BHT $0.01 \%$.
Lee, Hendricks and Cornforth (1999) also reported that the presence of the natural antioxidant carnosin increased the $\mathrm{pH}$ values in meat products. These authors compared the effect of carnosin $(1 \%)$ with ascorbic acid $(0.1 \%)$ and found that the $\mathrm{pH}$ values increased with the increase of carnosin concentration in the products.

As the interaction was disconnected, a linear increase $(\mathrm{p}<0.05)$ in $\mathrm{pH}$ values with storage time was observed for the antioxidants BHT $0.01 \%$, MSE $0.1 \%$, or MSE $0.2 \%$ according to the equations $5.90+0.007 \mathrm{x}, \mathrm{R}^{2}=0.89 ; \mathrm{y}=5.92+0.007 \mathrm{x}$, $\mathrm{R}^{2}=0.94$, and $\mathrm{y}=5.91+0.008 \mathrm{x}, \mathrm{R}^{2}=0.96$, respectively.

A linear increase in mortadella $\mathrm{pH}$ values during storage was also observed by Balev et al. (2005) in sausages stored for 30 days in temperatures varying from 8 to $11^{\circ} \mathrm{C}$.

The effects of the antioxidant treatments and the storage time on lipid oxidation (TBARS) of Bologna-type mortadella are shown in Table 3.

As indicated in Table 3, the antioxidant treatment had no significant $(\mathrm{p}>0.05)$ effect on TBARS. According to those results, MSE at 0.1 or $0.2 \%$ ratio had a similar effect to that of BHT $0.01 \%$.

The antioxidant activity observed in this study could be attributed to the phenolic contents and chemical properties of the MSE used. Phenolic antioxidants do not work as oxygen absorbers; instead they prevent formation of fatty free radicals, which react with or absorb oxygen during the process of lipid oxidation thus delaying the onset of the autoxidative process in fats or oils (NUNEZ-SELLES, 2005; SCHIBER; BERARDINI; CARLE, 2003). Moreover, Abdalla et al. (2007) reported that mango seed is also known as a good source of tocopherols with antioxidant potential.

Soong and Barlow (2004) found that the antioxidant activity of the mango seed extract increased after heating to $160{ }^{\circ} \mathrm{C}$. The authors attributed these results, at least in part, to the degradation of high molecular weight compounds at elevated heating temperatures releasing the free forms of gallic and ellagic acids. In addition, phenolic compounds may be formed during the heating process. Thus, in the present study, the temperature used in the preparation of Bologna-type mortadella $\left(78 \sim 80^{\circ} \mathrm{C}\right)$ may have contributed to enhance the antioxidant activity of MSE.

Rhee, Ziprin and Calhoun (2001) reported that the use of $3 \%$ cottonseed meal, which has also showed to be a good source

Table 2. $\mathrm{pH}$ values for Bologna-type mortadella containing butylated hydroxytoluene (BHT 0.01\%) or mango seed extract (MSE $0.1 \%$ or MSE $0.2 \%$ ) and stored at $2{ }^{\circ} \mathrm{C}$ for 21 days $^{(1)}$.

\begin{tabular}{|c|c|c|c|c|c|}
\hline \multirow[t]{2}{*}{ Antioxidant } & \multicolumn{5}{|c|}{ Time (days) } \\
\hline & 0 & 7 & 14 & 21 & Mean \\
\hline BHT $0.01 \%^{(2)}$ & $5.89 \pm 0.02^{\mathrm{Ac}}$ & $5.98 \pm 0.01^{\mathrm{Ab}}$ & $6.01 \pm 0.02^{\mathrm{Bb}}$ & $6.05 \pm 0.00^{\mathrm{Aa}}$ & $5.98 \pm 0.07$ \\
\hline MSE $0.1 \%^{(3)}$ & $5.91 \pm 0.01^{\mathrm{Ac}}$ & $5.98 \pm 0.01^{\mathrm{Ab}}$ & $6.04 \pm 0.00^{\mathrm{Aa}}$ & $6.06 \pm 0.01^{\mathrm{Aa}}$ & $5.99 \pm 0.07$ \\
\hline MSE $0.2 \%^{(4)}$ & $5.90 \pm 0.00^{\mathrm{Ad}}$ & $5.97 \pm 0.01^{\mathrm{Ac}}$ & $6.04 \pm 0.01^{\mathrm{Ab}}$ & $6.07 \pm 0.02^{\mathrm{Aa}}$ & $5.99 \pm 0.08$ \\
\hline Mean & $5.90 \pm 0.01$ & $5.98 \pm 0.01$ & $6.03 \pm 0.02$ & $6.06 \pm 0.01$ & - \\
\hline
\end{tabular}

${ }^{(1)}$ Mean values with different capital letters within a column or small letter within a row are significantly different $(\mathrm{p}<0.05)$; ${ }^{(2)} \mathrm{Linear}$ effect $\left(\mathrm{y}=5.90+0.007 \mathrm{x} ; \mathrm{R}^{2}=0.89\right)$; ${ }^{(3)} \mathrm{Linear}$ effect $\left(\mathrm{y}=5.92+0.007 \mathrm{x} ; \mathrm{R}^{2}=0.94\right) ;{ }^{(4)}$ Linear effect $\left(\mathrm{y}=5.91+0.008 \mathrm{x} ; \mathrm{R}^{2}=0.96\right) ; \mathrm{n}=4$. 
of phenolic antioxidants, was able to stop lipid oxidation in cooked meat stored at $4{ }^{\circ} \mathrm{C}$ for three days.

Lipid oxidation increased significantly $(\mathrm{p}<0.05)$ with refrigerated $\left(2{ }^{\circ} \mathrm{C}\right)$ storage, and a linear effect was observed according to equation $\mathrm{y}=0.18+0.01 \mathrm{x} ; \mathrm{R}^{2}=0.89$. Therefore, TBARS values for Bologna-type mortadella increased with storage time. The maximum acceptable limit of TBARS value in fatty foods, $1 \mathrm{mg} \cdot \mathrm{kg}^{-1}$, has been reported by Wu et al. (1991). TBARS values did not reach this value all through the storage period used in this study.

The effect of the antioxidant treatment and storage time on color components $\mathrm{L}^{*}, \mathrm{a}^{*}$ and $\mathrm{b}^{*}$ of Bologna-type mortadella are shown in Table 4 . An interaction $(\mathrm{p}<0.05)$ between the type of the antioxidant and storage time was observed for Bologna-type mortadella color component $\mathrm{L}^{*}$.

All color parameters $(\mathrm{p}<0.05)$ were affected by the addition of antioxidant extracts (MSE 0.1 or $0.2 \%$ ).

The highest $(p<0.05)$ values for the parameter $L^{\star}$ (lightness) were observed for mortadella containing BHT $0.01 \%$ after 7 , 14 , and 21 days of storage. The increase in lightness indicates increase in product paleness, which is perceived as a negative factor by meat product consumers. These results revealed that, MSE $(0.1$ or $0.2 \%)$ affected color stability in Bologna-type mortadella due to low values of lightness compared with those for the product containing BHT 0.01\%.

Chen et al. (1999) also reported that the presence of a natural antioxidant positively affected the lightness of pork patties. These authors compared the effect of rosemary oleoresin with BHT and found that the natural antioxidant had a strong antioxidant effect stabilizing product coloration.

These results are also in agreement with several researchers who reported that natural antioxidants have an effect on stabilizing coloration of meat and meat products, such as beef patties, mortadella, cooked chicken breast meat, and cooked turkey (BEKHIT et al., 2003; GHIRETTI et al., 1997; JO et al., 2006; YU et al., 2002).

The refrigerated $\left(2^{\circ} \mathrm{C}\right)$ storage for 21 days had no significant ( $p>0.05$ ) effect on $\mathrm{L}^{*}$ values in mortadellas containing BHT $0.01 \%$. However, in those containing MSE 0.1 or $0.2 \%$, the lightness values were lower than in those containing BHT $0.01 \%$ between the $7^{\text {th }}$ day and the $21^{\text {st }}$ day of storage.

For Bologna-type mortadella lightness, regression analysis indicated a quadratic effect $(\mathrm{p}<0.05)$ of storage time for the antioxidants MSE $0.1 \%$ or MSE $0.2 \%$ according to the equations $\mathrm{y}=62.02-0.32 \mathrm{x}+0.01 \mathrm{x}^{2} ; \mathrm{R}^{2}=0.77$ and $y=61.57-0.33 x+0.01 x^{2} ; R^{2}=0.76$, respectively. Therefore,

Table 3. Thiobarbituric acid-reactive substances (TBARS) values (mg MDA.kg-1 sample) for Bologna-type mortadella containing butylated hydroxytoluene (BHT $0.01 \%$ ) or mango seed extract (MSE $0.1 \%$ or MSE $0.2 \%$ ) and stored at $2{ }^{\circ} \mathrm{C}$ for 21 days ${ }^{(1)}$.

\begin{tabular}{lccccc}
\hline \multirow{2}{*}{ Antioxidant } & \multicolumn{4}{c}{ Time (days) } \\
\cline { 2 - 6 } & 0 & 7 & 14 & 21 & $0.32 \pm 0.01$ \\
\hline BHT 0.01\% & $0.18 \pm 0.01$ & $0.23 \pm 0.01$ & $0.30 \pm 0.04$ & $0.26 \pm 0.01^{\mathrm{A}}$ \\
MSE 0.1\% & $0.17 \pm 0.01$ & $0.23 \pm 0.04$ & $0.29 \pm 0.02$ & $0.34 \pm 0.01$ & $0.26 \pm 0.02^{\mathrm{A}}$ \\
MSE 0.2\% & $0.18 \pm 0.02$ & $0.22 \pm 0.00$ & $0.29 \pm 0.02$ & $0.34 \pm 0.03$ & $0.26 \pm 0.02^{\mathrm{A}}$ \\
Mean $^{(2)}$ & $0.18 \pm 0.00^{\mathrm{d}}$ & $0.23 \pm 0.01^{\mathrm{c}}$ & $0.29 \pm 0.01^{\mathrm{b}}$ & $0.33 \pm 0.01^{\mathrm{a}}$ & - \\
\hline
\end{tabular}

${ }^{(1)}$ Mean values with different capital letters within a column or small letter within a row are significantly different $(\mathrm{p}<0.05)$; ${ }^{(2)}$ Linear effect $\left(\mathrm{y}=0.18+0.01 \mathrm{x} ; \mathrm{R}^{2}=0.89\right)$; MDA, malondialdehyde; $\mathrm{n}=4$.

Table 4. Mean values for color parameters $\mathrm{L}^{\star}, \mathrm{a}^{\star}$, and $\mathrm{b}^{\star}$ of Bologna-type mortadella containing butylated hydroxytoluene (BHT $0.01 \%$ ) or mango seed extract (MSE $0.1 \%$ or MSE $0.2 \%$ ) stored for up to 21 days at $2{ }^{\circ} \mathrm{C}^{(1)}$.

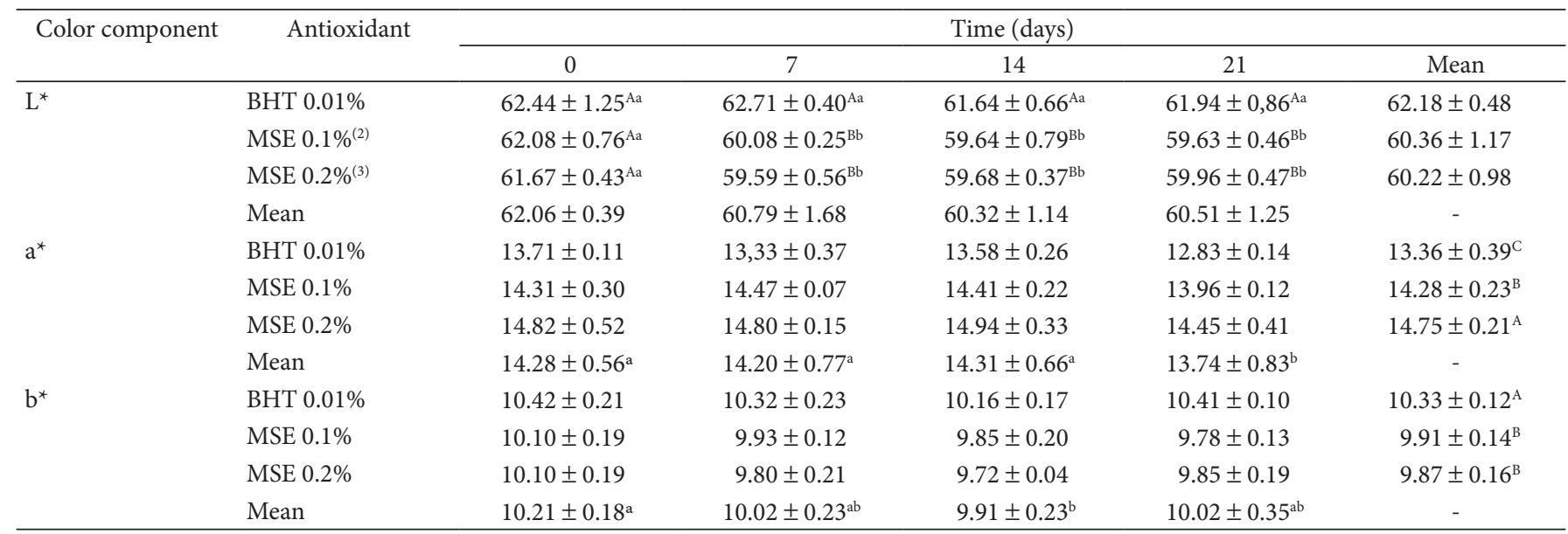

\footnotetext{
${ }^{(1)}$ Mean values with different capital letters within a column or small letter within a row are significantly different $(\mathrm{p}<0.05)$; ${ }^{(2)} \mathrm{Quadratic}$ effect $\left(\mathrm{y}=62.02-0.32 \mathrm{x}+0.01 \mathrm{x}^{2} ; \mathrm{R}^{2}=0.77\right)$;
}

${ }^{(3)}$ Quadratic effect $\left(\mathrm{y}=61.57-0.33 \mathrm{x}+0.01 \mathrm{x}^{2} ; \mathrm{R}^{2}=0.76\right) ; \mathrm{n}=4$. 
storage time produced minimum values of lightness with 16 days storage time on products containing MSE $0.1 \%$ or MSE $0.2 \%$.

The decrease in lightness of meat products during storage ( $4{ }^{\circ} \mathrm{C}$ for 15 days) has been previously reported by Bozkurt (2007) using sesame and Thymbra spicata oils as natural antioxidants.

The color parameter $\mathrm{a}^{\star}$ (redness) was higher for Bolognatype mortadellas containing MSE $(0.1$ or $0.2 \%)$ than those containing BHT $(0.01 \%)$. Moreover, the redness of Bolognatype mortadella increased $(\mathrm{p}<0.05)$ at higher concentrations of MSE. The highest $a^{*}$ value observed in mortadella containing MSE $0.2 \%$ was probably due to a darker color observed in this extract.

These results were also in agreement with Carpenter et al. (2007) who reported an increase in redness of cooked pork patties containing the highest concentrations of grape seed extract. Also, these authors observed that this increase in meat redness was not perceived as negative by the sensory panel.

The redness of Bologna-type mortadella was stable until the $14^{\text {th }}$ day of storage. However, on the $21^{\text {st }}$ day of refrigerated storage, $\mathrm{a}^{*}$ values decreased $(\mathrm{p}<0.05)$. The reduction of redness is perceived as a negative factor by meat consumers. These results suggested that the addition of BHT $(0.01 \%)$ or MSE $(0.1$ or $0.2 \%)$ have a protective effect on color during refrigerated storage until the $14^{\text {th }}$ day.

Bozkurt (2006) also found that after 15 days, turkish dryfermented sausage formulated with green tea extract reduced the intensity of the red color. The decrease of $\mathrm{a}^{*}$ values during storage is probably caused by the oxidation of the myoglobin pigment.

The highest $(\mathrm{p}<0.05)$ value for parameter $\mathrm{b}^{*}$ (yellowness) was obtained in mortadella with BHT 0.01\%. Similarly, Ahn; Grun and Mustapha (2007) reported that the yellowness in coked beef treated with synthetic antioxidants (BHA/BHT) was higher than that in meat with natural antioxidants (pine bark extract and oleoresin rosemary).

After 14 days of refrigerated storage, the Bologna-type mortadella decreased $(\mathrm{p}<0.05)$ in yellowness in all antioxidant treatments. The increase of yellowness is also perceived as a negative factor by the consumers. The decrease of $b^{*}$ values could be due to browning reactions, which form dark pigments, melanoidins, which contribute to the darkening of mortadella. Such browning reaction results from the reaction of reducing sugars and amino acids or proteins forming melanoidins. In meat products, this browning reaction is known as Maillard reaction and is one of the major causes of color deterioration. (KARABACAK; BOZKURT, 2008).

\section{Conclusions}

The inclusion of mango seed extract (MSE) at $0.2 \%$ in Bologna-type mortadella preparations promotes higher $\mathrm{pH}$ values after 14 and 21 days of storage at $2{ }^{\circ} \mathrm{C}$.
The natural antioxidant (MSE) efficiency to control lipid oxidation in mortadella is similar to that of the synthetic antioxidant $(0.01 \%$ butylated hydroxytoluene - BHT).

Storage time reduces lipid stability. However, meat rancidity is within the acceptable range for fatty foods.

The addition of MSE ( 0.1 or $0.2 \%)$ to Bologna-type mortadella preparation provides lower values of meat lightness after 7 days of storage at $2{ }^{\circ} \mathrm{C}$ as compared to those obtained with BHT $0.01 \%$. It also provides mortadella with good meat color stability for redness and yellowness.

Moreover, the use of MSE shows antioxidant effects similar or better than those of BHT. Therefore, MSE can be used in Bologna-type mortadella preparations to improve the quality of this meat product.

\section{Acknowledgements}

The authors thank Dr. Teresa Trevisan from LPN-UFC for obtaining the mango seed extract and to Mr. Manoel Alves from EMBRAPA - Agroindústria Tropical, Fortaleza, Ceará, Brazil, for assisting with the color analysis.

\section{References}

ABDALLA, A. E. M. et al. Egyptian mango by-product 2: Antioxidant and antimicrobial activities of extract and oil from mango seed kernel. Food Chemistry, v. 103, n. 4, p. 1141-1152, 2007.

AHN, J.; GRUN, I. U.; MUSTAPHA, A. Effects of plant extracts on microbial growth, colour change, and lipid oxidation in cooked beef. Food Microbiology, v. 24, n. 4, p. 7-14, 2007.

BALEV, D. et al. A comparative study on the effect of some antioxidants on the lipid and pigment oxidation in dry-fermented sausages. International Journal of Food Science and Technology, v. 40, n. 9, p. 977-983, 2005.

BEKHIT, A. E. D. et al. The effects of natural antioxidants on oxidative processes and metmyoglobin reducing activity in beef patties. Food Chemistry, v. 81, n. 2, p. 175-187, 2003.

BOZKURT, H. Comparison of the effects of sesame and Thymbra spicata oil during the manufacturing of Turkish dry fermented sausage. Food Control, v. 18, n. 4, p. 149-156, 2007.

BOZKURT, H. Utilization of natural antioxidants: green tea extract and Thymbra spicata oil in Turkish dry-fermented sausage. Meat Science, v. 73, n. 3, p. 442-450, 2006

BRASIL. Instrução Normativa $n^{\circ} 4$, de 31 de março de 2000. Regulamentos técnicos de identidade e qualidade de carne mecanicamente separada, de mortadela, de lingüiça e de salsicha. Anexo II - regulamento técnico de identidade e qualidade de mortadela. Diário Oficial [da] República Federativa do Brasil, Brasília, 2000.

BUB, A. et al. Fruit juice consumption modulates antioxidative status, immune status and DNA damage. The Journal of Nutritional Biochemistry, v. 14, n. 2, p. 90-98, 2003.

CARPENTER, R. et al. Evaluation of the antioxidant potential of grape seed and bearberry extracts in raw and cooked pork. Meat Science, v. 76, n. 4, p. 604-610, 2007.

CHEN, X. et al. Lipid oxidation, volatiles and colour changes of irradiated pork patties as affected by antioxidants. Journal of Food Science, v. 64, n. 1, p. 16-19, 1999. 
FACCO, E. M. P. Parâmetros de qualidade do charque relacionados ao efeito da suplementação de vitamina $\mathrm{E}$ na dieta de bovinos de raça Nelore em confinamento. Dissertação (Mestrado em Ciência de Alimentos)-Faculdade de Engenharia de Alimentos, Universidade Estadual de Campinas, Campinas, SP, 2002.

GHIRETTI, G. P. et al. Comparative Evaluation of Some Antioxidants in Salame Milano and Mortadella Production. Meat Science, v. 47, n. 1-2, p. 167-176, 1997.

HALLIWELL, B. Antioxidants in human health and diseases. Annual Review of Nutrition, v. 16, n. 1-2, p. 33-50, 1996.

JO S-C. et al. Antioxidant activity of Prunus mume extract in cooked chicken breast meat International Journal of Food Science and Technology, v. 41, n. 1, p. 15-19, 2006.

KANG, K. R.; CHERIAN, G.; SIM, J. S. Dietary palm oil alters the lipid stability of polyunsaturated fatty acid-modified poultry products. Poultry Science, v. 80, n. 2, p. 228-234, 2001.

KARABACAK, S.; BOZKURT, H. Effects of Urtica dioica and Hibiscus sabdariffa on the quality and safety of sucuk (Turkish dry-fermented sausage). Meat Science, v. 78, n. 3, p. 288-296, 2008.

LEE, B. J.; HENDRICKS, D. G.; CORNFORTH, D. P. A comparison of carnosine and ascorbic acid on color and lipid stability in a ground beef patties model system. Meat Science,v. 51, n. 3, p. 245-253, 1999.

MINOLTA CO. Precise color communication - color control from perception to instrumentation. Osaka: Minolta Co., 1998. 59 p.

NUNEZ-SELLES, A. J. Antioxidant therapy: myth or reality? Journal of the Brazilian Chemical Society, v. 16, n. 4, p. 699-710, 2005.

PURAVANKARA, D.; BOGHRA, V.; SHARMA, R. S. Effect of antioxidant principles isolated from mango (Mangifera indica L.) seed kernels on oxidative stability of buffalo ghee (butter-fat). Journal of the Science of Food and Agriculture, v. 80, n. 4, p. 522-526, 2000.

RAHARJO, S.; SOFOS, J. N.; SCHMIDT, G. R. Improved speed, specificity, and limit of determination of aqueous acid extraction thiobarbituric acid- $\mathrm{C}_{18}$ method for measuring lipid peroxidation in beef. Journal of Agricultural and Food Chemistry, v. 40, n. 11, p. 2182-2185, 1992.
RHEE, K. S.; ZIPRIN, Y. A.; CALHOUN, M. C. Atioxidative effects of cottonseed meals as evaluated. Meat Science, v. 58, n. 2, p. 117-123, 2001.

RIBEIRO, S. M. R. et al. Antioxidant in mango (Mangifera indica L.) Pulp. Plant Foods for Human Nutrition, v. 62, n. 1, p. 13-17, 2007.

SCHIBER, A.; BERARDINI, N.; CARLE, R. Identification of flavonol and xanthol glycosides from mango peels by HPLC. Journal of Agricultural and Food Chemistry, v. 51, n. 17, p. 5006-5011, 2003.

SILVA, J. G. et al. Avaliação da estabilidade e da qualidade do patê de presunto, adicionado de globina bovina e de caseinato de sódio, como agente emulsionante. Ciência e Tecnologia de Alimentos, v. 23, n. 1, p. 10-15, 2003.

SOONG, Y-Y.; BARLOW, P. J. Antioxidant activity and phenolic content of selected fruit seeds. Food Chemistry, v. 88, n. 3, p. 411-417, 2004.

SOONG, Y-Y.; BARLOW, P. J. Quantification of gallic acid and ellagic acid from longan (Dimocarpus longan Lour.) seed and mango (Mangifera indica L.) kernel and their effects on antioxidant activity. Food Chemistry, v. 97, n. 3, p. 524-530, 2006.

STATISTICAL ANALYSIS SYSTEM. SAS/STAT: User's guide. 12. ed. Version 6. Cary: SAS Institute Inc., 1999.

TANG, S. et al. Antioxidative effect of added tea catechins on susceptibility of cooked red meat, poultry and fish patties to lipid oxidation. Food Research International, v. 34, n. 8, p. 651-657, 2001.

WANASUNDARA, U. N.; SHAHIDI, F. Antioxidant and pro-oxidant activity of green tea extracts in marine oils. Food Chemistry, v. 63, n. 3, p. 335-342, 1998.

WARRIS, P. D. Ciencia de la Carne. 3. ed. Zaragoza, Espanha: Acríbia S.A., 2003. 309 p.

WU, W. H. et al. Starter culture and time/temperature of storage influences on quality of fermented mutton sausage. Journal of Food Science, v. 56, n. 4, p. 916-919, 1991.

YU, L. et al. Rosemary extracts as inhibitors of lipid oxidation and color change in cooked turkey products during refrigerated storage. Journal of Food Science, v. 67, n. 2, p. 582-585, 2002.

ZANDI, P.; GONDON, M. H. Antioxidant activity of extracts from old tea leaves. Food Chemistry, v. 64, n. 3, p. 285-288, 1999. 